\section{Scientific Rigor, Ethics of Publications, and the Temptation of Predatory Journals}

R. Mauricio Barría P.

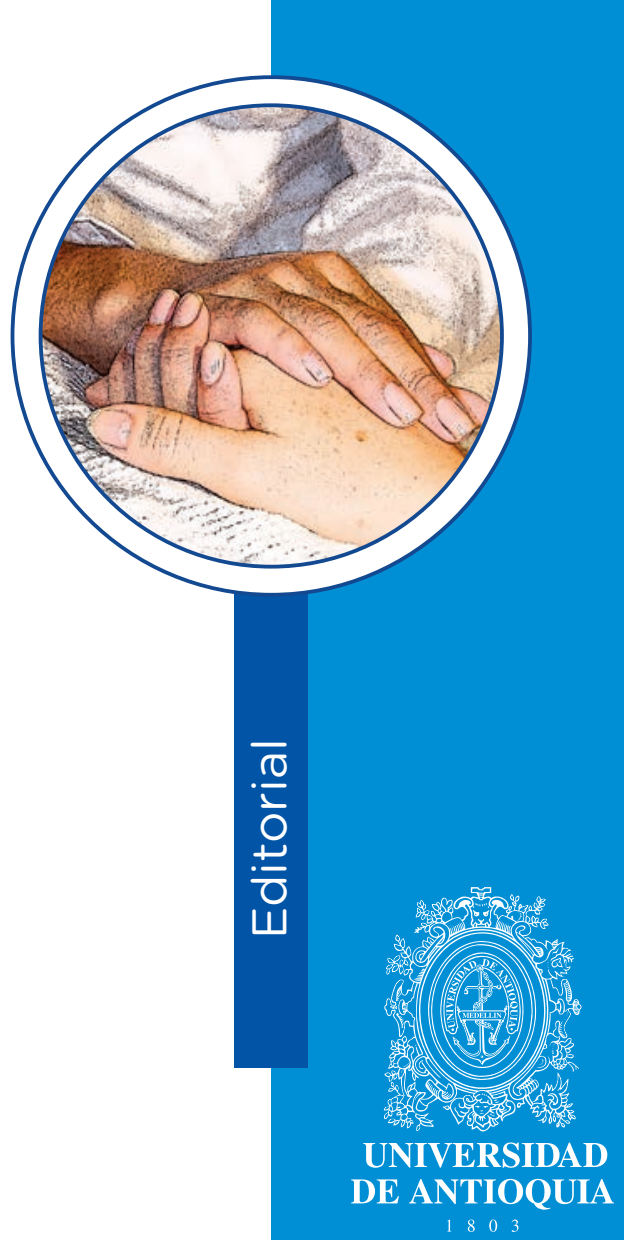

Generation of knowledge is fundamental for progress in different scientific disciplines and professions. Specifically, in health sciences no adequate technical-professional and disciplinary progress can be made if it is not as of research, which, in many cases, has been destined and confined to the academic setting. It is precisely in this scenario that the idea of publishing has prevailed, has been promoted, and required, which has pressured the scientific and academic community in the search for this objective, sometimes in a not very rigorous manner. ${ }^{(1)}$ According to the value assigned to scientific production if not published, they are limited and restricted in their hiring possibilities and academic promotions with the added impossibility of opting for improved wages.

Currently, even since some years back, it is possible to verify the increase in production of scientific research, which has resulted in an important increase in scientific production. Within this context, multiple options of journals have proliferated with an open access policy as alternative of broad and rapid dissemination of publications. Some sponsored by scientific societies, academic institutions,
1 RN, Ph.D. Director of the Nursing Institute, Faculty of Medicine, Universidad Austral de Chile. (Chile). email: rbarria@uach.cl

How to cite this article: Barría RM. Scientific Rigor, Ethics of Publications and the Temptation of Predatory Journals. Invest. Educ. Enferm. 2018;36(3):e01.

Dol: 10.17533/udea.iee.v36n3e01

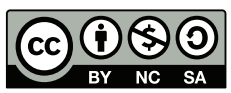


and public or private research entities whose objective is to have a rigorous means of dissemination that permits communicating research findings and academic opinions with a background of seriousness and responsibility. Nevertheless, unscrupulous groups have emerged that, supported on the idea of opening access to publications, have created journals that only seek a profitable business at the expense of researchers to whom the idea of publishing rapidly and massively seems attractive. This is how the so-called predatory journals have gained terrain and persist as alternatives to disseminate research and academic articles.

To date, there are several publications referring to the emergence of predatory journals. ${ }^{(2-6)}$ Specifically, all have described with variable depth the implications of this problem, since its origin, objective and repercussions for science and knowledge and it has been generally concluded that they constitute a sort of intellectual fraud with a merely commercial backdrop. It is only necessary to have published a couple of articles that are available on the web to become a potential prey for these predatory journals and be exposed to a certain intellectual plunder. The modus operandi has been described ${ }^{(2,7)}$ and it is fundamentally based on an e-mail message that kindly and in a very gentle and conceptual manner, values and congratulates a researcher for an article published and invites said researcher to submit similar articles or, even, extend or replicate the same article on account of a variable payment that depends on each journal. This offer could seem tempting, with the publication price discounts if the response is quick. It could be the opportunity to save that manuscript that did not prosper due to editorial rejections or because of a rigorous peer review.

However, researchers must understand that, although pressure exists for scientific production, they must weigh the ethical implications of losing academic vision and self-criticism by using these spaces to publish without major demands other than the monetary. It must be kept in mind that predatory journals constitute a dissemination alternative with serious ethical concerns. In principle, it must be considered how these journals introduce themselves with a distorted image about what they are and what they offer; furthermore, there is the lack of editorial and publication standards and practices, academic deception for allocating the efforts of authors to these journals, lack of real recognition of a good investigation, and loss of trust from readers and general public in scientific literature. ${ }^{(8)}$
In light of this situation, a difficult and complex scenario has been installed in which there is the idea of publishing merely to increase the number of publications in the antecedents and academic curricula, along with the high requirements of more prestigious journals that lessen the expectations of authors and become almost impregnable sites. However, another aspect as negative as publishing without sufficient rigor, is not publishing the findings of studies that required people, money, and time. ${ }^{(9)}$ It is likely that all these situations pressure researchers and academics and expose them to making difficult decisions. Should we publish articles that have not reached sufficient methodological standard of quality? Should we underestimate publishing an article that has been rejected by prestigious journals? What is the cost-benefit of publishing in an open-access journal that can be classified as a predatory journal? Will our academic prestige be affected if we publish in a predatory journal? Lastly, how can we discriminate if we are submitting a manuscript to a predatory journal?

Currently, the publication panorama is complex, and although consolidated journals of prestige consider that predatory journals do not constitute a real threat, credibility from each science, as well as from the scientific community comprised of researchers and academics are exposed to the lack of credibility by society. This is why academic institutions and other centers involved with research must assume the challenge imposed by the current moment of scientific dissemination spaces. As an ethical imperative, good science must be safeguarded. Thus, universities and research centers must ensure that research processes, from academics and students, be based on basic standards of scientific and ethical rigor, free of conflicts of interest (or, if it is the case, declare such), and that these be disseminated in journals with sufficient scientific and academic endorsement. For this, institutions must provide sufficient training and technical support to the members of the academic-scientific community and implement some measures to discourage illegitimate journals and reduce their attractive potential.

Lastly, from the perspective of an evidence-based practice, we value a scarce usefulness of articles included in these predatory journals as scientific evidence, given the limited editorial staff and poor or null peer review processes. However, given that they are easily available, it is now more necessary for health professionals, students, academics, and researchers to have sufficient skills for the critical appraisal of scientific articles that allow them to discriminate information according to its quality. 


\section{References}

1. Grimes DR, Bauch CT, loannidis JPA. Modelling science trustworthiness under publish or perish pressure. R. Soc. Open. Sci. 2018; 5(1):171511.

2. Delgado-Lopez PD, Corrales-Garcia EM. Predatory journals: una amenaza emergente para autores y editores de publicaciones biomedicas. Neurocirugia (Astur). 2018; 29(1):39-43.

3. Lewinski AA, Oermann MH. Characteristics of E-Mail Solicitations From Predatory Nursing Journals and Publishers. J. Contin. Educ. Nurs. 2018; 49(4):171-7.

4. Richtig G, Berger M, Lange-Asschenfeldt B, Aberer W, Richtig E. Problems and challenges of predatory journals. J. Eur. Acad. Dermatol. Venereol. 2018. 32(9):1441-9.

5. Beall J. What I learned from predatory publishers. Biochem. Med. (Zagreb) 2017; 27(2):273-8.

6. Beall J. Best practices for scholarly authors in the age of predatory journals. Ann. R. Coll. Surg. Engl. 2016; 98(2):77-9.

7. Moher D, Srivastava A. You are invited to submit. BMC Med. 2015;13:180.

8. Ferris LE, Winker MA. Ethical issues in publishing in predatory journals. Biochem. Med. (Zagreb). 2017; 27(2):27984.

9. Frank E. Publish or perish: the moral imperative of journals. CMAJ 2016; 188(9):675. 